\title{
Growth performance of Tectona grandis Linn F. between two thinning operations at Shankarnagar, western Terai, Nepal
}

\author{
H. B. Thapa ${ }^{1}$ and S. K. Gautam ${ }^{2}$
}

\begin{abstract}
Tectona grandis plot was established on $7^{\text {th }}$ July 1992 in 0.50 hectare at a spacing of $2.5 \mathrm{~m} \times 2.5 \mathrm{~m}$ at Shankarnagar, Rupandehi district, in the western Terai of Nepal. Estimated average fresh wood production of 14.5 years old teak was found to be $226 \mathrm{~kg}$ (201 tons ha $^{-1}$ ) before thinning and $125 \mathrm{~kg}$ (53 tons ha-1) in thinned trees and $318 \mathrm{~kg}$ (148 tons $\mathrm{ha}^{-1}$ ) for trees after thinning. Above ground green biomass was estimated to be $134 \mathrm{~kg}$ tree $^{-1}$ (57 tons ha-1) for thinned trees, $240 \mathrm{~kg}^{-1} \mathrm{ree}^{-1}\left(214\right.$ tons ha $\left.{ }^{-1}\right)$ for trees before thinning and $337 \mathrm{~kg}^{-1} \mathrm{tre}^{-1}\left(157\right.$ tons $\left.\mathrm{ha}^{-1}\right)$ for trees after thinning. Prior to thinning, the mean over bark stem volume was $0.2313 \mathrm{~m}^{3}$. In thinning, $59 \mathrm{~m}^{3}$ per ha-1 volume was removed. The volume of standing trees before thinning at 14.5 years was $206 \mathrm{~m}^{3} \mathrm{ha}^{-1}$. After thinning, per unit and mean basal area, biomass and over bark stem volume has been increased considerably during 7-years from 7.5 years to 14.5 years. Shankarnagar Community Forest User Group has earned NRs. $60,000.00$ by selling thinned yield i.e. poles and fire wood
\end{abstract}

Keywords: Tectona grandis, growth, biomass, volume, rotation, thinning, Nepal

$I^{\mathrm{n}}$ n Nepal, record of first governmental teak plantation was in 1960 in Chiliya, Rupandehi District (Kayastha 1974). After that, Forests Products Development Board has established some block plantations at Sagarnath, Sarlahi and Ratuwamai, Jhapa. Department of Forest Research and Survey has established some research plots of teak at Sagarnath, and private growers have planted teak on their private land in different parts of the country

Teak has high demand in national as well as international market because of its excellent quality wood. It is widely used for boat and ship building, construction, decorative veneers, joinery, furniture, cabinets, musical instruments, poles, branches for fire wood and handicrafts/wood carving due to its natural durability and dimensional stability. A third grade T. grandis plantation may be more profitable than a first graded plantation of a less valuable species (Jackson 1994).

The information on growth, predicted yield from second thinning would be valuable for community and private plantations as well. This paper attempts to provide information on growth, thinning yield at 14.5 years, growth, wood and foliage biomass, and aboveground biomass from 7.5 to 14.5 years.

\section{Materials and Methods}

Teak was planted on $7^{\text {th }}$ July 1992 in 0.50 hectare at a spacing of $2.5 \mathrm{~m} \times 2.5 \mathrm{~m}$ at Shankarnagar, Rupandehi District, in the western Terai of Nepal. The site is located at latitude $27^{\circ} 42^{\prime} \mathrm{N}$ and longitude $83^{\circ} 28^{\prime} \mathrm{E}$. Its altitude is about $205 \mathrm{~m}$ above msl. The climate is sub-tropical monsoon with an average annual rainfall $2452 \mathrm{~mm}$ (20 years record cited in Jackson 1994)). Generally, the site is dry from November to May, however occasional light shower occurs in the winter. Mean maximum and minimum temperature are $30.21^{\circ} \mathrm{C}$ and $20.21^{\circ} \mathrm{C}$ respectively, absolute maximum temperature being $44.9^{\circ} \mathrm{C}$ in May and absolute minimum temperature $4.3^{\circ} \mathrm{C}$ in January (based on 15 years record, cited in Jackson 1994).

The stumps were planted, which were raised in District Forest Office nursery in Bhairahawa, Rupandehi District. Up to three years, spot cultivation ( $0.5 \mathrm{~m}$ radius) was carried out twice a year. Height and diameter were measured in each winter. Prior to second thinning carried out in March, 2007, some operations were carried out in the winter of different years, for instance pruning in 1996, pruning and singling in 1999 and selection thinning in 2000 . At 14.5 years, diameter at breast height (dbh) of all 
trees was measured before thinning. Out of total 445 trees, 213 dead, dying, diseased, suppressed, poorly grown, few dominant and co-dominant trees were marked for thinning. Thirty-two trees, which were broken by wind, were not included in the study. Out of these marked trees, 25 trees were used for biomass study. After felling, the total length of the tree was measured. Wood (stem and branch) and foliage were weighed separately.

Nine discs were taken from bottom, middle and top portion of the tree (three discs from each portion). Two diameters were measured and mean diameter was calculated for each disc with bark. The same method was applied to find out the diameter of the disc without bark. Length of each disc was measured. Each fresh disc with bark was weighed in the field. Again, fresh discs were weighed after removing the bark. All the discs were kept in an oven drier at $105^{\circ} \mathrm{C}$ for 48 hours and weighed again. Volume, weight of fresh and oven-dried discs (with and without bark) were summed up and average fresh and oven-dried density of disc was calculated.

\section{Results and Discussion}

\section{Height and Diameter Growth}

The growth results of height and diameter of teak planted at Shankarnagar, Rupandehi cover from 7.5 years to 14.5 years (Table 1 ). In Chilia, Rupandehi District, 14 years teak had $15.2 \mathrm{~m}$ of mean height, with periodic annual increment (pai) $1.09 \mathrm{~m}$ (Kayastha 1974), whereas the mean height was $17.2 \mathrm{~m}$ at Shankarnagar at 14.5 years with pai $1.2 \mathrm{~m}$. Height growth was found better at Shankarnagar than Chilia in Rupandehi district. As mentioned by Kayastha (1974) the roots in the Chilia plantation were not able to penetrate the compact layer formed by higher percentage of silt and clay, which might have reduced the growth. Such problem is not found in Shankarnagar teak plantation.

In this study, slight variation in periodic diameter increment $(1.2-1.5 \mathrm{~cm})$ is recorded in different years. It is decreased with the increase in age of the trees. Periodic height increment is also similar to the rate of growth of diameter (Table 1). Obviously, rate of growth of trees becomes slow as the trees get older.

In a teak plantation established at a spacing of $3 \mathrm{~m} \mathrm{x}$ $3 \mathrm{~m}$ in June-July 1988 at $27 \mathrm{~km}$ southeast of Darwin on a reasonable level site with laterite/clay soil, mean dbh was $16.2 \mathrm{~cm}$ at a stocking level of 621 stems ha1. A handful of fowl manure was applied around each individual tree at planting (Robertson et al. 2005). The diameter growth is higher at Shankarnagar, indicating better site than the site at south west of Darwin.

The fastest growth recorded in teak plantations in the world is from Chittagong District, Bangladesh at Kaptai. Trees of 21 years old had average height of $29.3 \mathrm{~m}$ with pai $1.4 \mathrm{~m}$ and average diameter of $30 \mathrm{~cm}$ with pai $1.4 \mathrm{~cm}$ (Parameswarappa 1995). At Shankarnagar, pai figures of height and diameter of 14.5 years teak are $1.2 \mathrm{~m}$ and $1.2 \mathrm{~cm}$ respectively. The trend of present growth of teak in this site does not meet the growth of teak at Kaptai, Bangladesh. It indicates that growth of teak is greatly affected by the site quality. At 20 years of age the height growth was $23.1 \mathrm{~m}$ with pai $1.2 \mathrm{~m}$ and diameter was $23.1 \mathrm{~cm}$ with pai $1.4 \mathrm{~cm}$ in Indo Gangetic Belt of Haldwani Division, U. P. India ( Parameswarappa 1995 ). In this study, pai of height at 14.5 years is the same as the pai of height in Haldwani Division, but the pai

Table 1: Growth of Tectona grandis after first thinning at 7.5 years

\begin{tabular}{|c|c|c|c|c|c|c|c|c|c|c|c|}
\hline $\begin{array}{l}\text { Age } \\
\text { (year) }\end{array}$ & $\begin{array}{l}\text { Stock } \\
\text { ing } \\
(\text { trees } \\
\left.\text { ha }^{-1}\right)\end{array}$ & $\begin{array}{c}\text { Mean } \\
\text { height }(\mathrm{m})\end{array}$ & $\begin{array}{l}\text { Std. } \\
\text { error } \\
(\mathrm{m})\end{array}$ & $\begin{array}{l}\text { CV } \\
(\%)\end{array}$ & $\begin{array}{l}\text { CAI of } \\
\text { height } \\
\text { (m) }\end{array}$ & $\begin{array}{l}\text { PAI of } \\
\text { height } \\
\text { (m) }\end{array}$ & $\begin{array}{l}\text { Mean dbh } \\
\quad(\mathrm{cm})\end{array}$ & $\begin{array}{l}\text { Std. } \\
\text { error } \\
(\mathrm{cm})\end{array}$ & $\begin{array}{l}\text { CV } \\
(\%)\end{array}$ & $\begin{array}{c}\text { CAI } \\
\text { of } \mathrm{dbh} \\
(\mathrm{cm})\end{array}$ & $\begin{array}{c}\text { PAI } \\
\text { of } \\
\text { dbh } \\
(\mathrm{cm})\end{array}$ \\
\hline 7.5 & 943 & $12.4(7.2-17.5)$ & 0.09 & 9.7 & - & - & $11.7(6-17.8)$ & 0.09 & 17.1 & - & - \\
\hline 8.5 & 943 & $13.2(7.6-18.8)$ & 0.09 & 15.2 & 0.8 & 1.6 & $12.6(6.5-19.4)$ & 0.11 & 18.3 & 0.9 & 1.5 \\
\hline 9.5 & 940 & $14.3(9-20.8)$ & 0.11 & 15.4 & 1.1 & 1.5 & $13.9(8-22)$ & 0.13 & 18.7 & 1.3 & 1.5 \\
\hline 10.5 & 938 & $14.7(9.5-22)$ & 0.12 & 16.3 & 0.4 & 1.4 & $14.5(8.5-23.4)$ & 0.14 & 20.0 & 0.6 & 1.5 \\
\hline 11.5 & 922 & $15.2(6.1-23.2)$ & 0.13 & 17.8 & 0.5 & 1.3 & $15.0(4.9-25)$ & 0.16 & 21.3 & 0.5 & 1.5 \\
\hline 12.5 & 922 & $15.8(6-24.3)$ & 0.14 & 19.0 & 0.6 & 1.3 & $15.7(4.8-26.5)$ & 0.17 & 22.9 & 0.7 & 1.3 \\
\hline 13.5 & 916 & $16.5(9.8-25.8)$ & 0.16 & 20.0 & 0.7 & 1.2 & $16.6(8.8-28.5)$ & 0.20 & 24.1 & 0.9 & 1.2 \\
\hline 14.5 & 890 & $17.2(9.2-28.8)$ & 0.17 & 21.5 & 0.7 & 1.2 & $17.6(8.1-32.5)$ & 0.21 & 26.1 & 1.0 & 1.2 \\
\hline
\end{tabular}

CAI and PAI refer to current and periodic annual increment. 7.5 years and 14.5 years results refer to results after thinning and before thinning respectively. The figures in the parenthesis refer to the range of height and dbh. Height are estimated based on the model, Ln Height $=0.493531+0.82341 * \mathrm{Ln} \mathrm{DBH}$ (except for 7.5 years) $\left(\mathrm{R}^{2}=81.9 \%\right.$, number of observations: 306$)$. 
of diameter $(1.2 \mathrm{~cm})$ is less than that place. After thinning, the pai of height and diameter is changed from $1.2 \mathrm{~m}$ and $1.2 \mathrm{~cm}$ to $1.4 \mathrm{~m}$ and $1.4 \mathrm{~cm}$ respectively. It is expected that the trend of height and growth will be similar to the height and diameter growth in Harldwani Division after this second thinning.

In Bastar of Madhya Pradesh, India, 24-years old teak acquired a diameter growth of $38 \mathrm{~cm}$ with pai $1.6 \mathrm{~cm}$, which is an appreciable growth (Reddy 1995). In the districts of Visakhapatnam and East Godavari, in Andhra Pradesh, 11-years old teak plantation in Rajaomangi Reserve had attained dbh $23.1 \mathrm{~cm}$ with pai $2.1 \mathrm{~cm}$ and height $12.46 \mathrm{~m}$.. Similarly, dbh and height of 13-years old teak in Rajaomangi Reserve Forest were $24.7 \mathrm{~cm}$ and $14 \mathrm{~m}$ respectively (Reddy 1995). Diameter growth is certainly higher in Bastar and Rajaomangi, although height growth is higher at Shankarnagar than these two places. Teak plantation was established in 1986 by Ichalkaranji Co-operative Spinning Mills at Ichalkaranji District Kolhapur in the Western Maharashtra Dry Zone, India. In addition to the normal practices, the plantation was raised at a regular flood irrigation at an interval of 3 to 4 weeks, during the dry season. The firm used a lot of cotton waste/linter to fertilise the teak plantation. As a consequence to such high inputs, sampling attained average dbh of $9.1 \mathrm{~cm}$ $(28.5 \mathrm{~cm}-\mathrm{GH}$ O. B.) and $10.8 \mathrm{~m}$ height at the age of 7-years (Gogate 1995). The growth is better at Shankarnagar, even without application of fertilizer and irrigation. It may be due to the moist condition and higher fertility of this site, which is favourable for the good growth of teak.

Teak was planted in 1963 in Pakela Reserved Forest Block of Sukma Range of South Bastar Division, India. Topography is almost flat with an elevation of $171 \mathrm{~m}$ above msl. Soil is rich alluvium, deep and sandy loam. At the age of 14-years, teak attained mean dbh of $15.5 \mathrm{~cm}$ (5 to $25 \mathrm{~cm}$ ) with pai $1.1 \mathrm{~cm}$ (Suri 1984). The diameter growth is higher at Shankarnagar. The study was undertaken at Nimbia Forest Research situated at about $70 \mathrm{~km}$ south of Jos, in a small pocket of the Derived Savanna woodland, Nigeria. Its altitude is $640 \mathrm{~m}$. The soil is of Katchuk loam series derived from basement complex. At 7years the height and diameter of teak were $8.3 \mathrm{~m}$ and $12.6 \mathrm{~cm}$ at a spacing of $3.66 \times 2.74 \mathrm{~m}\left(996\right.$ trees ha $\left.{ }^{-1}\right)$. At the same age, height and diameter were $7.7 \mathrm{~m}$ and $12.1 \mathrm{~cm}$ respectively (Adegbehin 1982) at a spacing of $3.66 \times 3.66 \mathrm{~m}$ (748 trees ha $\left.{ }^{-1}\right)$. Diameter growth of teak at Shankarnagar is slightly lower, but the height growth is higher than the Nimbia Forest Reserve.

Based on the site quality II in India, mean diameter and mean height of 15 -years old teak are $15.75 \mathrm{~cm}$ and $15.54 \mathrm{~m}$ respectively (Maslekar 1981), whereas the mean diameter and mean height of 14.5-years old teak at Shankarnagar are $17.6 \mathrm{~cm}$ and $17.2 \mathrm{~m}$ respectively. The growth is slightly better than the site quality II in India. So, it is obvious that the Shankarnagar site is similar to site quality II in India.

Due to removal of all suppressed trees in thinning at 7.5 years, remaining trees had more or less similar height, so the coefficient of variation (CV) was low $(9.7 \%)$. CV of diameter was $17.1 \%$ at 7.5 years, which was $27 \%$ before thinning (Thapa and Gautam 2005). As expected, uniformity in height and diameter decreased gradually due to annual variation in height and diameter growth of individual trees after 7.5 years. CV of height ranged from $9.7 \%$ at 7.5 years to $21.5 \%$ at 14.5 years. In case of diameter, CV ranged from $17.1 \%$ at 7.5 years to $26.1 \%$ at 14.5 years (Table 1).

Stocking ranges from 943 trees after thinning at 7.5 years to 890 trees before thinning at 14.5 years. The change in stocking from one year to another is mainly due to damage of trees by wind in different years. In this study 32 trees were found damaged by wind. It clearly indicates that teak plantations also need shelterbelt, if there is a problem of strong wind.

\section{Basal area and other parameters of thinned and standing trees}

After thinning, mean height and dbh are increased $2.6 \mathrm{~m}(15.1 \%)$ from $17.2 \mathrm{~m}$ to $19.8 \mathrm{~m}$ and $3.1 \mathrm{~cm}$ $(17.6 \%)$ from $17.6 \mathrm{~cm}$ to $20.7 \mathrm{~cm}$ respectively. Particularly, such increase in size of trees has main role in accumulation of wood for timber. Further it can increase the quality of wood and reduce the rotation period of trees. For trees prior to thinning and after thinning at 7.5 years, mean basal areas were $0.0089 \mathrm{~m}^{2}$ and $0.0111 \mathrm{~m}^{2}$ respectively (Thapa and Gautam 2005) whereas mean basal areas were 0.0258 $\mathrm{m}^{2} 0.0345 \mathrm{~m}^{2}$ respectively at 14.5 years. The basal area is significantly higher at 14.5 years than the basal area at 7.5 years (Table 2). It is mainly due to effect of first thinning on growth of trees. During 7 years, a significant increase in basal area per hectare 12.5 $\mathrm{m}^{2} \mathrm{ha}^{-1}(120 \%)$ from $10.4 \mathrm{~m}^{2}$ ha ${ }^{-1}$ at 7.5 years to 22.9 
$\mathrm{m}^{2} \mathrm{ha}^{-1}$ is recorded. About $48 \%$ trees have been thinned and $30.3 \%$ basal area is removed in thinning at 14.5 years.

Over bark stem volume is increased $121.8 \mathrm{~m}^{3} \mathrm{ha}^{-1}$ (145\%) from $84.2 \mathrm{~m}^{3} \mathrm{ha}^{-1}$ at 7.5 years to $206 \mathrm{~m}^{3} \mathrm{ha}^{-1}$ at 14.5 years, which is a substantial volume accumulation during 7 -years period (Table 2). The mean over bark stem volume of teak was $0.2313 \mathrm{~m}^{3}$ before thinning at 14.5 years. The volume of thinned trees was $147 \mathrm{~m}^{3} \mathrm{ha}^{-1}$ whereas the volume of standing trees before thinning was $206 \mathrm{~m}^{3} \mathrm{ha}^{-1}$. About $28.6 \%$ of the total volume was removed in thinning operation (Table 2).

In a 14.4 years teak plantation near Darwin, mean basal area was $13.1 \mathrm{~m}^{2} \mathrm{ha}^{-1}$ at a stocking level of 621 stems ha ${ }^{-1}$ (Robertson et al. 2005), whereas basal area of 14.5 years old teak is higher $\left(22.9 \mathrm{~m}^{2} \mathrm{ha}^{-1}\right)$ at

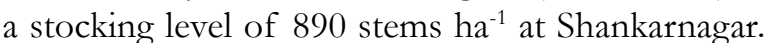
Teak trial with nine provenances was established at a spacing of $3 \mathrm{mx} 2 \mathrm{~m}$ in the Top End of the Northern Territory on dark brown sandy clay with a high water table at Humpty Doo, $57 \mathrm{~km}$ southeast of Darwin, in January 1973. Approximately 100 grams of NPK fertilizer was applied per tree at planting. In the trial of Humpty Doo, a provenance from Kerala in India had a basal area of $24.08 \mathrm{~m}^{2} \mathrm{ha}^{-1}$ with pai $2.5 \mathrm{~m}^{2}$ ha ${ }^{1}$ year $^{-1}$ at age 9.6 years and basal area increased to $40.43 \mathrm{~m}^{2} \mathrm{ha}^{-1}$ with pai $2.0 \mathrm{~m}^{2} \mathrm{ha}^{-1}$ year $^{-1}$ at 20 -years (Cracium 1973).

Stem timber volume of 21-years teak trees at Kaptai, Chittagong District, Bangladesh was $34.09 \mathrm{~m}^{3}$ acre $^{-1}$ $\left(81.8 \mathrm{~m}^{3} \mathrm{ha}^{-1}\right)$ whereas small timber volume was 8.86 $\mathrm{m}^{3}$ per acre $\left(21.2 \mathrm{~m}^{3} \mathrm{ha}^{-1}\right)$. At Kaptai, Bangladesh, the teak grows faster than Nilambur first quality teak in India in general and attains higher volume per acre. (Parameswarappa 1995). The total over bark stem volume is $145 \mathrm{~m}^{3} \mathrm{ha}^{-1}$ at 14.5 years after thinning which is higher than Kaptai. In 1963 plantation in Pakela Reserved Forest Block of Sukma Range of South Bastar Division, 14-years old teak has produced $92.2 \mathrm{~m}^{3} \mathrm{ha}^{-1}$ of wood against the expectation of $70.4 \mathrm{~m}^{3} \mathrm{ha}^{-1}$, which is estimated growth based on yield tables of site quality II (Suri 1984). The higher volume in this study may be due to over bark volume and inclusion of volume up to the top portion of tree. Generally, stem volume is under bark and up to the certain part of the tree i.e. $4 \mathrm{~cm}$ or $10 \mathrm{~cm}$ top diameter of the tree.

Basal area of 14-years old teak in Pakela Reserved Forest Block of Sukma Range of South Bastar Division was $12.7558 \mathrm{~m}^{2} \mathrm{ha}^{-1}$ (stocking: 550 trees ha $\left.{ }^{1}\right)$, against the expectation of $10.4569 \mathrm{~m}^{2} \mathrm{ha}^{-1}$ which is based on yield tables of site quality II (stocking 477 trees ha ${ }^{-1}$ ) (Suri 1984). Basal area of 14.5 years teak after second thinning (stocking 464 trees ha $^{-1}$ ) is slightly higher at Shankarnagar. It indicates that the site quality of Shankarnagar falls in the site quality II in India.

At Nimbia Forest Research situated at about $70 \mathrm{~km}$ south of Jos, in a small pocket of the Derived Savanna woodland, Nigeria, 7-years old teak planted at a spacing of $3.66 \times 2.74 \mathrm{~m}$ attained the basal area $12.8 \mathrm{~m}^{2} \mathrm{ha}^{-1}$ and volume $39.3 \mathrm{~m}^{3} \mathrm{ha}^{-1}$. Similarly, at the same age teak planted at a spacing of $3.66 \times 3.66 \mathrm{~m}$ attained the basal area $8.7 \mathrm{~m}^{2} \mathrm{ha}^{-1}$ and volume 26.2 $\mathrm{m}^{3} \mathrm{ha}^{-1}$ (Adegbehin 1982). In a 20 years old teak plantation in Teliamura Forest Division in Tripura

Table 2: Height, dbh, basal area, periodic annual increment of basal area, and over bark stem volume of 14.5 years Tectona grandis

\begin{tabular}{|c|c|c|c|}
\hline \multirow{2}{*}{ Parameter } & \multirow{2}{*}{ Thinned trees } & \multicolumn{2}{|c|}{ Standing trees } \\
\hline & & Before thinning & After thinning \\
\hline Mean height (m) & 14.5 & 17.2 & 19.8 \\
\hline Mean dbh $(\mathrm{cm})$ & 14.2 & 17.6 & 20.7 \\
\hline Mean basal area $\left(\mathrm{m}^{2}\right.$ tree $\left.^{-1}\right)$ & 0.0164 & 0.0258 & 0.0345 \\
\hline Basal area $\left(\mathrm{m}^{2} \mathrm{ha}^{-1}\right)$ & 6.9 & 22.9 & 16.0 \\
\hline $\begin{array}{l}\text { Periodic annual increment of basal area } \\
\left(\mathrm{m}^{2} \mathrm{ha}^{-1} \mathrm{year}^{-1}\right)\end{array}$ & 0.48 & 1.6 & 1.1 \\
\hline Over bark stem volume $\left(\mathrm{m}^{3}\right.$ tree $\left.^{-1}\right)$ & 0.1384 & 0.2313 & 0.3166 \\
\hline Over bark stem volume $\left(\mathrm{m}^{3} \mathrm{ha}^{-1}\right)$ & 59 & 206 & 147 \\
\hline $\begin{array}{l}\text { Periodic annual increment of over bark } \\
\text { stem volume }\left(\mathrm{m}^{3} \mathrm{ha}^{-1} \mathrm{year}^{-1}\right)\end{array}$ & 4.0 & 14.2 & 10.1 \\
\hline Stocking (stems ha $\left.{ }^{-1}\right)$ & 426 & 890 & 464 \\
\hline $\begin{array}{l}\text { Percentage of the original stocking ( } 1600 \\
\left.\text { trees } \mathrm{ha}^{-1}\right)\end{array}$ & 26.6 & 55.6 & 29.0 \\
\hline
\end{tabular}


Table 3: Mean green biomass of thinned and standing trees before and after thinning at 14.5 years

\begin{tabular}{|c|c|c|c|c|c|c|}
\hline \multirow[b]{2}{*}{ Parameter } & \multirow{2}{*}{$\begin{array}{l}\text { Thinned } \\
\text { trees }(\mathrm{kg} \\
\left.\text { tree }^{-1}\right)\end{array}$} & \multicolumn{2}{|c|}{ Standing trees $\left(\mathrm{kg}\right.$ tree $\left.^{-1}\right)$} & \multirow{2}{*}{$\begin{array}{l}\text { Thinned } \\
\text { trees (tons } \\
\text { ha }^{-1} \text { ) }\end{array}$} & \multicolumn{2}{|c|}{ Standing trees (tons ha $\left.{ }^{-1}\right)$} \\
\hline & & $\begin{array}{l}\text { Before } \\
\text { thinning }\end{array}$ & $\begin{array}{c}\text { After } \\
\text { thinning }\end{array}$ & & $\begin{array}{l}\text { Before } \\
\text { thinning }\end{array}$ & $\begin{array}{c}\text { After } \\
\text { thinning }\end{array}$ \\
\hline $\begin{array}{l}\text { Above-ground } \\
\text { total wood }\end{array}$ & 125 & $226(94)$ & 318 & 53 & $201(94)$ & 148 \\
\hline Foliage & 9 & $14(6)$ & 19 & 4 & $13(6)$ & 9 \\
\hline $\begin{array}{l}\text { Above-ground } \\
\text { biomass }\end{array}$ & 134 & $240(100)$ & 337 & 57 & $214(100)$ & 157 \\
\hline \multicolumn{7}{|c|}{$\begin{array}{l}\text { Figures in parenthesis indicate the percentage of wood and foliage in total aboveground biomass. Use the following figures to convert green } \\
\text { wood and foliage to oven dry wood and foliage. Green wood to oven dried wood }=0.4232 \quad \text { Green foliage to oven dried foliage }=0.3586 \text { The } \\
\text { models were used from Thapa and Gautam (2005) Green wood }(\operatorname{LnW})=-1.9276+2.5206 * \operatorname{Ln} \text { DBH, Green foliage }(\operatorname{Ln} W)=-2.9556+1.9362 * \operatorname{Ln} \\
\text { DBH }\end{array}$} \\
\hline
\end{tabular}

State, India., the mean annual increment of bole was $7.919 \mathrm{~m}^{3} \mathrm{ha}^{-1} \mathrm{year}^{-1}$, the total volume being $158.38 \mathrm{~m}^{3}$ ha $^{-1}$ (stocking 414 trees ha ${ }^{-1}$ ) (Negi et al. 1990).

\section{Biomass}

Before thinning, estimated average fresh wood and foliage production of 14.5 years old teak was found to be $226 \mathrm{~kg}\left(201\right.$ tons ha $\left.^{-1}\right)$ and $14 \mathrm{~kg}$ (13 tons ha $\left.{ }^{-1}\right)$; $125 \mathrm{~kg}\left(53\right.$ tons ha $\left.{ }^{-1}\right)$ and $9 \mathrm{~kg}\left(4\right.$ tons ha $\left.{ }^{-1}\right)$ in thinned trees; $318 \mathrm{~kg}\left(148\right.$ tons ha $\left.{ }^{-1}\right)$ and $19 \mathrm{~kg}\left(9\right.$ tons ha $\left.^{-1}\right)$ respectively for trees after thinning (Table 3).

In this study, the contribution of green foliage in total aboveground biomass was $6 \%$ only, whereas it was $8 \%$ at 7.5 years.. Less foliage at 14.5 years may be due to more foliage fallen on the ground, as this thinning was done later than the first thinning at 7.5 years. So, the figure of fresh foliage presented in Table 3 is less than the actual biomass figure of foliage. Contribution of foliage in total above-ground biomass is mainly affected by three factors: leaf fall, smaller sized and less number of branches. In a 20 years old teak plantation in Teliamura Forest Division in Tripura State, India., the above-ground wood (twig, branch, bark and bole) accounted for 95\% (108 tons $\left.\mathrm{ha}^{-1}\right)$ and the leaf accounted for 5\% (6 tons ha $\left.{ }^{-1}\right)$ in oven-dried total above-ground biomass (114 tons ha ${ }^{1}$ ) (Negi et al. 1990). The contribution of aboveground wood and foliage in above-ground total biomass of teak is almost the same in both the places. At Shankarnagar, oven-dried total above-ground biomass of 14.5 years old teak before thinning is
89.7 tons ha ${ }^{-1}$, which is lower than Tripura, as teak at Shankarnagar is five years younger than Tripura. It is expected to get that yield at 20-years at Shankarnagar.

From this thinning, Shankarnagar Community Forest User Group has sold 250 poles at the rate of NRs. 80 per pole and 100 quintals of fire wood at the rate of Rupee 1 per kilo. So the total amount of money from poles and fire wood is Rupees 60, 000 ( 1 US $\$$ =NRs. 62.00) per hectare, in which the labour cost for felling, sectioning and transporting the materials is not included. It clearly indicates that one can get poles for sale after second thinning of teak. These poles can be used in house construction. The number of poles will certainly increase in subsequent thinning operations. If preservative treatment is applied for the poles and posts obtained from thinning, the monetary value would be even higher. It is essential to consider such aspect to get higher value in future.

\section{Productivity and Density}

Before thinning at 14.5 years, productivity of green wood (stem and branch) of teak was 13.9 tons ha ${ }^{-1}$ year ${ }^{-1}$ and rate of accumulation was found to be 15.6 $\mathrm{kg} \mathrm{tree}^{-1} \mathrm{year}^{-1}$ (Table 4). Similarly Joshi (1982) found that productivity of green wood of 10.5 years old teak at Sagarnath was 13.07 tons ha ${ }^{-1}$ year ${ }^{-1}$. The productivity of green wood is more or less similar in both sites, Shankarnagar and Sagarnath. It indicates that both sites have similar features for the growth of teak.

Table 4: Productivity and rate of accumulation of green biomass of 14.5 years $T$. grandis

\begin{tabular}{|c|c|c|c|c|c|c|}
\hline & \multicolumn{3}{|c|}{ Green biomass (kg tree year $^{-1}$ ) } & \multicolumn{3}{|c|}{ Green biomass (tons ha-1 year $^{-1}$ ) } \\
\hline & $\begin{array}{l}\text { Total } \\
\text { wood }\end{array}$ & Foliage & $\begin{array}{l}\text { Total above- } \\
\text { ground biomass }\end{array}$ & Total wood & Foliage & $\begin{array}{c}\text { Total above-ground } \\
\text { biomass }\end{array}$ \\
\hline Before thinning & 15.6 & 1.0 & 16.6 & 13.9 & 0.9 & 14.8 \\
\hline After thinning & 21.9 & 1.3 & 23.2 & 10.2 & 0.6 & 10.8 \\
\hline
\end{tabular}


Table 5 : Per unit area basal area, green and oven-dry biomass (wood and foliage), over bark stem volume of standing trees in different years

\begin{tabular}{|c|c|c|c|c|c|c|c|c|}
\hline \multirow{2}{*}{ Age } & \multirow{2}{*}{$\begin{array}{c}\text { Basal area } \\
\left(\mathrm{m}^{2} \mathrm{ha}^{-1}\right)\end{array}$} & \multicolumn{3}{|c|}{ Green biomass (tons ha-1) } & \multicolumn{3}{|c|}{ Oven dry Biomass (tons ha-1) } & \multirow{2}{*}{$\begin{array}{l}\text { Over bark stem } \\
\text { volume }\left(\mathrm{m}^{3} \mathrm{ha}^{-1}\right)\end{array}$} \\
\hline & & Wood & Foliage & Total & Wood & Foliage & Total & \\
\hline 7.5 & 10.4 & 71.4 & 5.8 & 77.2 & 30.3 & 2.1 & 32.4 & 84.2 \\
\hline 8.5 & 12.2 & 86.7 & 6.8 & 93.5 & 36.8 & 2.4 & 39.2 & 99.9 \\
\hline 9.5 & 14.9 & 111.8 & 8.3 & 120.1 & 47.6 & 2.9 & 50.5 & 125.0 \\
\hline 10.5 & 16.0 & 123.5 & 8.9 & 132.4 & 52.8 & 3.2 & 56.0 & 136.1 \\
\hline 11.5 & 17.1 & 133.5 & 9.4 & 142.9 & 58.6 & 3.4 & 62.0 & 145.0 \\
\hline 12.5 & 18.8 & 153.3 & 10.4 & 163.7 & 64.9 & 3.7 & 68.6 & 164.0 \\
\hline 13.5 & 21.0 & 176.7 & 12.0 & 188.7 & 74.8 & 4.3 & 79.1 & 185.0 \\
\hline 14.5 & 23.0 & 200.7 & 12.6 & 213.3 & 84.9 & 4.5 & 89.4 & 205.8 \\
\hline
\end{tabular}

7.5 years results and 14.5 years refer to results after thinning and before thinning respectively. Results from 7.5 to 11.5 years are from Thapa and Gautam (2005).

The productivity of oven-dried above-ground biomass (wood and foliage) of teak in Tripura was 5.7 tons $\mathrm{ha}^{-1}$ year $^{-1}\left(114\right.$ tons $\mathrm{ha}^{-1}$ at the age of 20 years) whereas it was. 3.4 tons $\mathrm{ha}^{-1}$ year $^{-1}$ in U. P. (130 tons ha ${ }^{-1}$ at the age of 38 years) (Negi et al. 1990). The productivity of oven-dried above-ground biomass of teak at Shankarnagar is higher ( 6.2 tons $\mathrm{ha}^{-1}$ year $\left.^{-1}\right)$ than both the places. It indicates that the performance of growth performance of teak is reasonable at Shankarnagar.

Over bark (ob) and under bark (ub) density of green wood are found $1162 \mathrm{kgm}^{-3}$ and $1236 \mathrm{kgm}^{-3}$ respectively. Density of ob and ub oven dried wood is significantly decreased (459 $\mathrm{kgm}^{-3}$ for ob wood and $444 \mathrm{kgm}^{-3}$ for ub wood).

Per unit area and mean basal area, biomass and over bark stem volume after thinning

The basal area of trees per unit area depends upon the size and density of trees. At Sagarnath, Sarlahi, the basal area of $22.1 \mathrm{~m}^{2} \mathrm{ha}^{-1}$ was recorded in 10.5 years old teak having its pai $2.1 \mathrm{~m}^{2} \mathrm{ha}^{-1}$ year ${ }^{-1}$ (Joshi 1982) whereas its basal area in that age at Shankarnagar was found lower $\left(16 \mathrm{~m}^{2} \mathrm{ha}^{-1}\right)$ than Sagarnath. It may be due to lower stocking at Shankarnagar.

Basal area per unit area ranged from $10.4 \mathrm{~m}^{2} \mathrm{ha}^{-1}$ at 7.5 years to $23 \mathrm{~m}^{2} \mathrm{ha}^{-1}$, an increase of $121 \%$ during 7 -years. Similarly, green wood ranged from 71.4 tons $\mathrm{ha}^{-1}$ to 200.7 tons ha $^{-1}$ ( $181 \%$ increase) at 14.5 years, green foliage from 5.8 tons ha ${ }^{-1}$ to 12.6 tons $\mathrm{ha}^{-1}$ (117\% increase) and over bark stem volume $84.2 \mathrm{~m}^{3}$ $\mathrm{ha}^{-1}$ to $205.8 \mathrm{~m}^{3} \mathrm{ha}^{-1}$ (144\% increase) during that period (Table 5). All of these figures state that the growth of trees has been increased in a significant manner after first thinning. Similar trend is found in biomass and volume production. The remaining trees after thinning have got more space so that nutrient availability increased which caused an increase in biomass and volume production during that period.

\section{Conclusion}

Promotion of teak plantation can be successfully done in the Terai region of Nepal, as it is supported by the growth results of teak plantation at Shankarnagar, Rupandehi District. On the one hand, timely thinning certainly promote the growth of remaining trees, and on the other, farmers or communities get return by selling poles and fire wood from each thinning operation.

\section{References}

Adegbehin, J. O. 1982. Preliminary results of the effects of spacing on the growth and yield of Tectona grandis Linn. F. Indian Forester 108 (6): 423430.

Cracium, G. 1973. Species testing results-Hardwoods. Position Paper No. 3. Northern Territory Administration Branch.

Gogate, M. G. 1995. Evaluation of growth response of Teak to high inputs. Indian Forester 121 (6) : 578-580.

Jackson, J. K. 1994. Manual of Afforestation in Nepal, Second edition. Forestry Research and Survey Centre, Nepal.

Joshi, M. R. 1982. Preliminary estimate of the productivity of plantation grown Tectona grandis and Dalbergia sissoo at Sagarnath, Nepal. Forest Survey and Research Office. Publication no. 36. 
Kayastha, B. P. 1974. Site suitability of trial plantations of Teak (Tectona grandis). Forestry (4), 4-7. Journal of the Institute of Forestry.

Maslekar, A. R. 1981. Forester's Companion (Indian Forestry Handbook). Jugal Kishore and Company, Dehradun.

Negi, J. D. S., Bahuguna, V. K., and Sharma, D. C.1990. Biomass production and distribution of nutrients in 20 years old Teak (Tectona grandis) and Gamar (Gmelina arborea) plantation in Tripura. Indian Forester 116 (9): 681-686.

Parameswarappa, S. 1995. Teak - how fast can it grow and how much can it pay?. Indian Forester 121 (6): 563-565.

Reddy, Jagannath C. 1995. The Bounty from the teak tree. Indian Forester 121 (6): 573-575.
Robertson, R. M. and Reilly, D. F. 2005. Performance of a 16-year-old stand of Teak (Tectona grandis $\mathrm{L}$. F.) in the Darwin area in relation to that in other trials in the Northern Territory. Information Booklet. Department of Primary Industry, Fisheries and Mines.

Suri, S. K. 1984. A suggested model for quantitative assessment of plantations with particular reference to Pakela Teak plantations of South Bastar Division (M. P.). Indian Forester 110 (3): 253263.

Thapa, H. B. and Gautam, S. K. 2005. Growth performance of Tectona grandis in the western Terai of Nepal. Banko Janakari 15 (2): 6-12. 